\section{Unwise Tenement-House Legislation}

To the Editor:-Your editorial discussion in lust week's issue (2\% 52) of tenement legislation prompts me to add these considerations, Rents are high on Manhattan Islund beonuse the demand for space in which to live is beyond the supply. Also the rent is artificially and unnecessarily made still more prohibitive by two recent mensures offered by the Charity Organization Soeiety, und made a law April, 19i2.

The first measure was a requirement that the water-eloset in the Vanderbilt tenement, and in fact in all the open-stair tenements, and in future buildings of that type should be placed on the valuable and limited outside wall space known as the periphery, whereas adequate ventilation and lighting was provided for the water-closet on the "court stair recess" through a window, view-proof even when open. The New York Acrdemy of Medicine, the Tenement Economies Society and many other societies, as well as individuals, regret this added load on the small wage-earner. This alone is prohibitive, probably adding 12 per cent. to the already high rent.

The second measure was to make the limit of a room 7 feet. At first sight this would seem reasonable: it is hardly fair to ask a family to consider " space narrower than 7 feet. But if 7 , why not 8 or 9 ? We are decidedly meddling with another man's pouket-book; what if a family cun pay only for a room if feet across? It must be remembered that the law had always fixed a limit, $\mathrm{us}$ it does still, of 70 square feet of floor-space in a room with a ceiling 9 - feet high. Why suddenly tix the width sit 7 feet?

Some of the Vanderbilt rooms are only 6 feet 6 inches across; some rooms in the open-stair tenements are 6 foet. They all rent readily. People prefer smull, well-ventilated and lighted space to dark quarters that are larger. Besides, it is obvious that a fumily eal separate the sexes, the young from the old and the sick from the well by menns of a number of small bedrooms rather than a few large ones. Morality, modesty and refinement are dulled through lack of privacy. This lnw of April, 1912, will work great havoe which its promoter's did not foresee.

For instance, there was in course of preparation a tenement laving the economic advantage of open stairs which placed on a lot 100 feet square a building of sixty-four rooms per floor, ench containing not less than 70 square feet of aren, and with one room in ench suite containing not less than 120 square feet. Every room latd a large window to a street, a yard or a spncious open court. No other building had ever before been planned for more than fifty-six rooms in the same space. Some of these sixty-four rooms were to be 6 feet across; by making them 7 feet, eight rooms would be lost.

Here was a distinct advantage to the small wage-earner crippled by an ill-conceived. law promoted by the Churity Organization Socjety, but legretted much by the Tenement Economies Society.

All smaller cities of the United States are apt to be influ. enced by largor onos. New Yor'k should not be oflered as a model for multiple buildings owing to her unusual eramped condition and her lack of adequnte transportation facilities; but; unfortunately, her exmmple is followed and her exmmple. in tenements is not even semiscientific. Corrective measures, however, are in sight and the poor mny yet find light and air instead of durkness and filth.

Henux ATtemuny Smrti, New York.

\section{Esperanto and the Medical Profession}

To the E'ditor:-Twenty-five years ago Esperunto was introcluced by a Polish oenlist, Dr. Kamenthof. The propaganda since then has resulted in a world-wide knowledge of Esperunto, and physicians in many lands have been quick to grasp the advan. tage of unhampered correspondence or conference with their colleagues, unhindered by difference of national. language.

About five yeurs ago an association known as "Tutmonda Esperantista Linracista Asocio" (world-wide association of Esperantist plyysicians) was formed, and at each of the intermational Esperanto congresses thre has been a special session of this association. During the period of its existence it laas publislıed an official organ which, like all struggling medical publications, has had a checkered existence. At the last congress, held in Cracow during the past summer, after a most enthusiastic conference, the question of a permanent officinl organ was finally and satisfactorily settled. Two numbers of this journal, which is a sixteen-page publication, Kuracisto (Doctor), have already been published. The first number was largely made up of reports of the congress and also published a paper on actinomycosis by a Swiss oculist, which had been read at that congress. The leading articles of the second numr ber are an exhaustive paper on extra-uterine pregnancy and another on the treatment of tuberculosis with tuberculin. This number also contains severad reviews of leading articles in liuropean medical publications.

Both the association and its organ should appeal to the man who wishes to get in touch with the medical men and medical methods in various countries. Muny physicians in the American Medical Association are alrendy enrolled as member's of the Esperanto Association of North America; still more have a working knowledge of Esperanto, and this number would be increased tenfold if it were known what a simple and practical solution of $\mathrm{nn}$ international language Esperanto really is. Several linglish firms liave issued special Esperanto cutalogues and literature. 1 is is safe to conchude that this action is not taken without reason.

Esperantist plyysicians who wish for further information are requested to communicate with the undersigned.

\section{H. Fessenden, M.D., Newton Center, Mass.}

\section{Effects of Drinking Water with Meals}

To the bditor:-The beneficial eflects of drinking water with meuls, recently referred to in Tile Jounnal (Nov. 30, 1912, p. 1975), are present only when the water is takon slowly, a little at a time and not too cold. If, as is frequently practiced by many people, the water is gulped down ice-cold, a glassful or so at a timo, then instead of being useful, it may become very injurious indeed.

We are often called to treat people with severe cramps sud. denly developed during or right after a meal. In many of these casos we often find that the sufierer drank large quantities of too cold water. So though the dilution of an enzyme cloes not interfere with its activity, cold, as is well known, returds its netion. Hence the drinking of too cold water with meals is liable, with some people at least, seriously to interfere with their digestion and cause them useless suffering. It would be well, when advising people to tako water with their mens, to eaution them of the harmfulness of too cold water, especially when taken excessively.

L. Buckis, New York.

\section{Poliomyelitis and the Paralytic Type of Rabies}

To the Edditor:-Dr. Henry F. Langhorst's article "Possible Transmission of Poliomyelitis 'lhrough the Dog" (The JounNAL, Dec. 28, 1912, p. 2312) should call attention to the great difficulty of differentinting in mun between the paralytic type of rabies and certain other nervous disenses.

In the literature one'often sees allusions to the difficulty of discriminating between' the paralytic type of rabies and Landry's disease; these cases should also put us on our guard against confusing this type of rabies with poliomyelitis.

James M. Phit..IPs, M.D., Columbus; Ohio.

Insanity and Heredity. $\rightarrow$ A periodically insane son or daugh. ter is more likely to be associated with a periodically insane mother or father than if one is differently affected. In the case of two ofl'spring in the insane there is even a grenter tendency for a periodically insane male or female to be asso. cinted with a periodically insane brother or sister than with. one differently aflected.-Edward Shuster and Henry A. Cot. ton in dim. Jour. Insan. 